\title{
Studies toward the Total Synthesis of GKK1032A, a Structurally Unique Anti- tumor Compound: Stereoselective Construction of the Tricarbocyclic System
}

\author{
Noriyoshi Arai, ${ }^{\text {a }}$ Hideaki Ui, ${ }^{\mathrm{b}}$ Satoshi Omura, ${ }^{\mathrm{c}}$ Isao Kuwajima*a \\ a Creation and Function of New Molecules and Molecular Assemblies, Core Research for Evolutional Science and Technology (CREST), \\ Japan Science and Technology Agency (JST), 1-15-1 Kitasato, Sagamihara, Kanagawa 228-8555, Japan \\ Fax +81(42)7789931; E-mail: kuwajima@lisci.kitasato-u.ac.jp \\ b School of Pharmaceutical Science, Kitasato University, 5-9-1 Shirokane, Minato-ku, Tokyo 108-8641, Japan \\ c The Kitasato Institute, 5-9-1 Shirokane, Minato-ku, Tokyo 108-8642, Japan \\ Received 15 April 2005
}

\begin{abstract}
The unique tricarbocyclic system in $\mathrm{GKK}_{1032 \mathrm{~A}_{2} \text {, an }}$ antitumor agent from Penicillium sp. GKK1032, was constructed in a highly stereoselective manner, starting from a readily available Hajos-Wiechert ketone analog.

Key words: antitumor agents, carbocycles, Diels-Alder reactions, natural products, stereoselective synthesis
\end{abstract}

GKK1032 $\mathrm{A}_{2}$ is a member of a novel class of antibiotic antitumor compounds recently isolated from Penicillium sp. GKK1032 (Figure 1). ${ }^{1,2}$ These compounds exhibit potent activity against bacteria including drug-resistant strain, as well as antitumor activity against epithelioid cell HeLa S3. ${ }^{1 \mathrm{a}} \mathrm{He}$ et al. isolated pyrrocidines A and B, 3,6-bisepi-3desmethyl analogues of GKK1032s, and reported that they showed similar bioactivity. ${ }^{3}$ From a pharmaceutical point of view, these bioactivities make GKK1032 family an expecting candidate for a drug to control mutidrug-resistant Staphylococcus aureus and other nosocomial infections, and a new seed for anti-cancer drug. Structural feature of the compound was elucidated by NMR techniques and X-ray crystallographic analysis, ${ }^{1 b}$ which includes an unique 6-5-6 tricarbocyclic system and an unusual 13-membered macrocyclic ether containing 1,4disubstituted phenyl moiety. Recently, Oikawa disclosed that the unique backbone of GKK1032 $\mathrm{A}_{2}$ is biosynthetically constructed from L-tyrosine and a nonaketide chain with five methyl groups. ${ }^{4}$

These biologically and synthetically attracting features of GKK1032 family prompted us to embark on the total synthesis of GKK1032A .

The synthetic plan is shown in Scheme 1. The macrocyclic moiety of $\mathbf{1}$ could be constructed from an aldehyde $\mathbf{2}$ via carbon chain elongation followed by ring-closure. The cyclohexene ring in $\mathbf{2}$ is expected to be formed by DielsAlder reaction between a diene $\mathbf{3}$ and an appropriate dienophile which may occur from the upper face of the diene taking advantage of a steric effect of the aromatic ring. The diene 3 would be readily accessible from a known bicyclic ketone $4^{5}$ available with high optical

SYNLETT 2005, No. 11, pp 1691-1694

Advanced online publication: 14.06.2005

DOI: 10.1055/s-2005-871549; Art ID: U10005ST

(C) Georg Thieme Verlag Stuttgart · New York
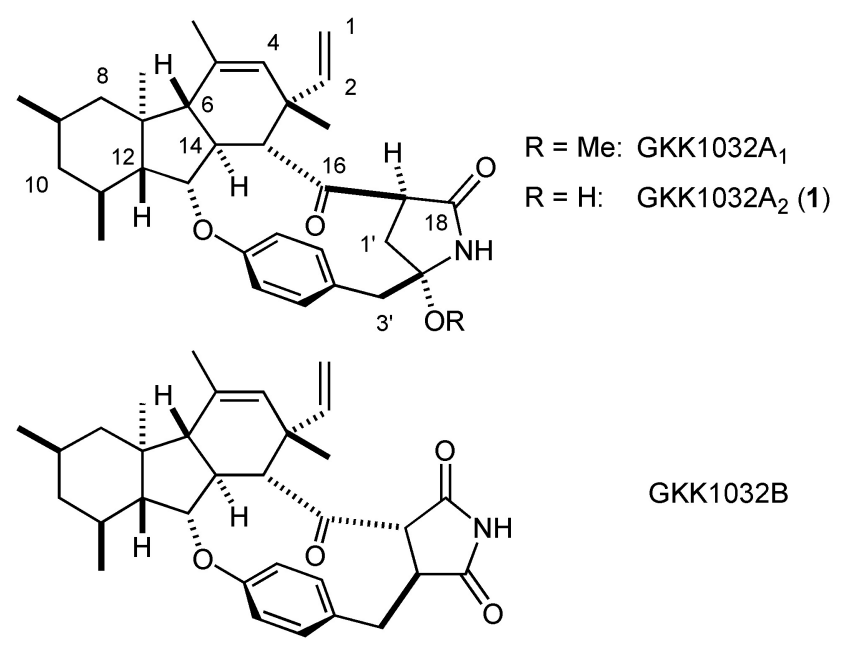

GKK1032B

Figure 1 Structures of GKK1032 family.

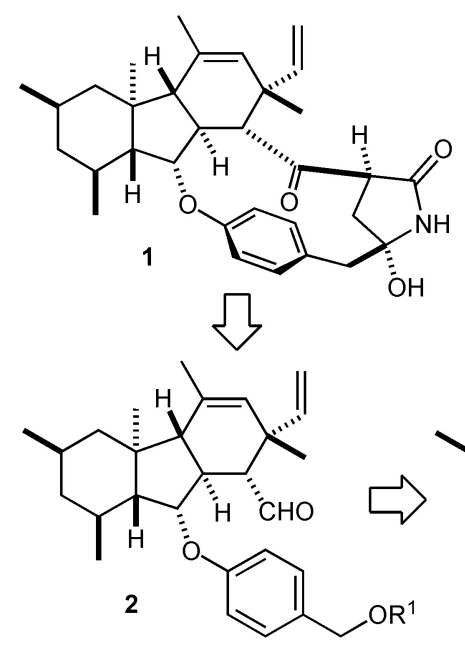<smiles>CC1=C2CCC(=O)[C@@]2(C)CCC1=O</smiles>

$\mathrm{OH}$

Scheme 1 Retrosynthetic analysis of GKK1032A 2 .

purity. We describe herein a method to construct the tricarbocyclic system of GKK1032s in a highly stereoselective manner, starting from a readily available HajosWiechert ketone analogue 4.

The bicyclic ketone $\mathbf{4}$ was regio- and stereoselectively reduced and protected with TBS group ${ }^{5}$ to afford an enone 5 (Scheme 2). For the trans selective reduction of 6-5 
bicyclic enone related to $\mathbf{5}$, we preferred a catalytic hydrogenation procedure convenient for multi-gram scale preparation at the early stage of the total synthesis. On the catalytic hydrogenation of this type of compounds, it was reported that the larger is a substituent at $\alpha$-position of the enone [corresponding to $\mathrm{C}(11)-\mathrm{Me}$ in 5, GKK1032A numbering], the higher trans selectivity is observed, ${ }^{6}$ though unsubstituted substrates gave cis major product. ${ }^{7,8}$ Indeed, the hydrogenation of $\mathbf{5}$ proceeded with high trans selectivity in THF to afford $\mathbf{6}$ via a subsequent epimerization under basic conditions. Use of the dry solvent was essential to achieve the high trans selectivity, otherwise the selectivity was markedly decreased, and in some case inverted. Methylation of $\mathbf{6}$ under kinetic conditions followed by epimerization produced a ketone 7 in good yield. A secondary alcohol $\mathbf{8}$ obtained by conventional deoxygenation ${ }^{9}$ of $\mathbf{7}$ was converted into an enone $\mathbf{9}$ via Swern oxidation ${ }^{10}$ and dehydrogenation under Tsuji's conditions. ${ }^{11}$

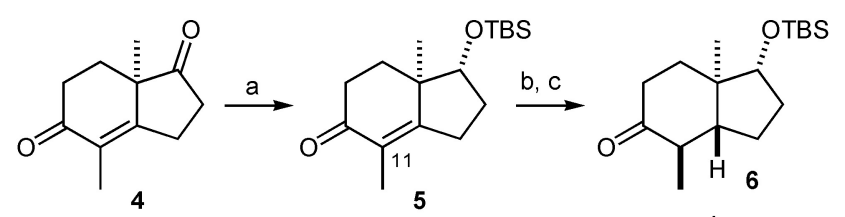

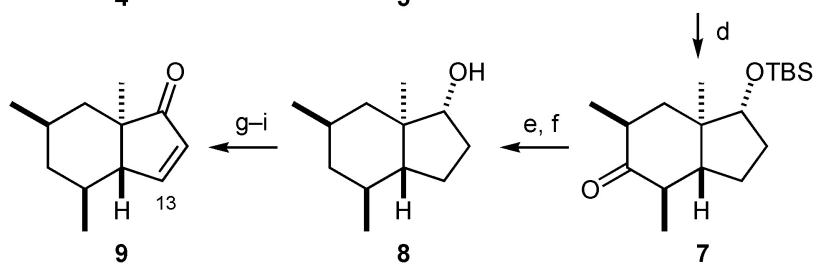

Scheme 2 Reagents and conditions: a) ref. 5; b) $\mathrm{H}_{2}, \mathrm{Pd} / \mathrm{C}$, THF, $0{ }^{\circ} \mathrm{C}, 1 \mathrm{~d}$, trans $/$ cis = ca. $9: 1$; c) $\mathrm{NaOEt}$, EtOH, reflux, $6 \mathrm{~h}, 77 \%(2$ steps); d) LDA, THF, $-78{ }^{\circ} \mathrm{C}, 3 \mathrm{~h}$, then $\mathrm{MeI},-78{ }^{\circ} \mathrm{C}$ to r.t., $85 \%$; e) 1,2-ethanedithiol, $\mathrm{BF}_{3} \cdot \mathrm{OEt}_{2}$, neat, $0{ }^{\circ} \mathrm{C}$ to r.t., $1 \mathrm{~d}, 85 \%$; f) Raney $\mathrm{Ni}$ $(\mathrm{W}-2), \mathrm{EtOH}$, reflux, $14 \mathrm{~h}, 76 \%$; $)(\mathrm{COCl})_{2}, \mathrm{DMSO}, \mathrm{Et}_{3} \mathrm{~N},-78$ to $0{ }^{\circ} \mathrm{C}, 1 \mathrm{~h}, 93 \%$; h) LDA, THF, $-78{ }^{\circ} \mathrm{C}, 3 \mathrm{~h}$, then TMSCl; i) $10 \mathrm{~mol} \%$ $\mathrm{Pd}(\mathrm{OAc})_{2}$, allyl carbonate, $\mathrm{MeCN}$, reflux, $67 \%$ (2 steps).

For the stereoselective introduction of an oxygen functionality at C(13)-position, we decided to utilize Krafft's procedures: they reported a suprafacial 1,3-rearrangement of the hydroxyl group of tertiary allylic alcohol obtained by addition of 2-lithio-2-methyl-1,3-dithiane to cyclopentenone moiety in a steroid derivative under dilute acidic conditions. ${ }^{12}$ Their protocol worked well also in our case: Addition of the lithiodithiane to the enone 9 took place selectively from the opposite side of the angular methyl group and a subsequent treatment with dilute sulfuric acid afforded allylic alcohol $\mathbf{1 1}$ in excellent stereoselectivity (Scheme 3). Introduction of the aryl ether was effectively achieved by using aromatic $\mathrm{S}_{\mathrm{N}} 2$ reaction between a fluoroarene chromium complex and an alkoxide of $\mathbf{1 1},{ }^{13}$ followed by decomplexation with CAN. ${ }^{14}$ The deprotection of the dithiane turned out to be somewhat troublesome, probably due to a steric factor and the instability of the aryl ether moiety under the reaction conditions. ${ }^{15}$ After several trials, it was found that application of Stork's method ${ }^{16}$ as well as Panek's protocol ${ }^{17}$

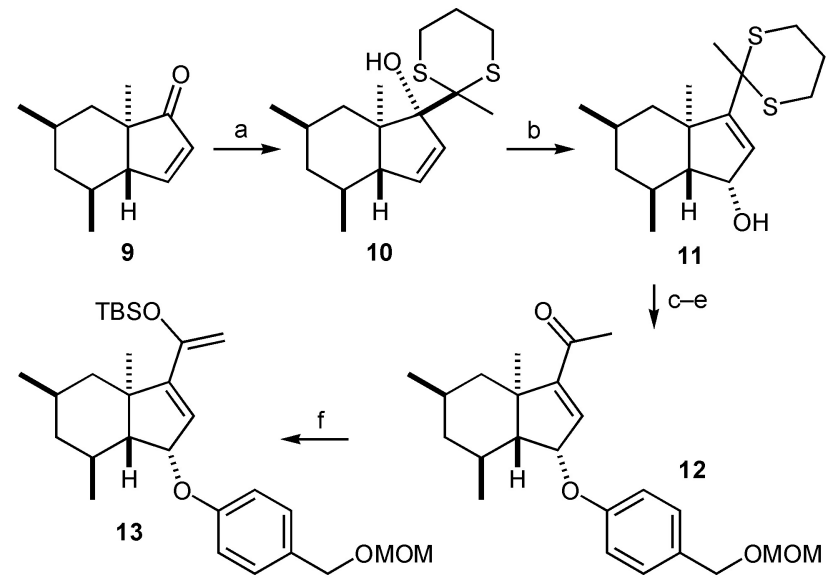

Scheme 3 Reagents and conditions: a) 2-lithio-2-methyl-1,3-dithiane, THF, -78 to $-23{ }^{\circ} \mathrm{C}, 5 \mathrm{~h}, 97 \%$; b) $0.5 \% \mathrm{H}_{2} \mathrm{SO}_{4}$, aq THF, $0{ }^{\circ} \mathrm{C}$ to r.t., $1 \mathrm{~d}, 77 \%$ ( 3 recycles), >20:1 stereoselectivity; c) NaH, $\eta^{6}-4-$ $\mathrm{FC}_{6} \mathrm{H}_{4} \mathrm{CH}_{2} \mathrm{OMOM}-\mathrm{Cr}(\mathrm{CO})_{3}$, THF, reflux, $7 \mathrm{~h}, 81 \%$; d) CAN, $\mathrm{NaHCO}_{3}, \mathrm{MeCN},-23{ }^{\circ} \mathrm{C}, 20 \mathrm{~min}, 82 \%$; e) Dess-Martin periodinane, $\mathrm{MeCN}-\mathrm{CH}_{2} \mathrm{Cl}_{2}-\mathrm{H}_{2} \mathrm{O}$, r.t., 39 h, 70\%; f) KHMDS, TBSCl, THFHMPA, $-78^{\circ} \mathrm{C}$ to r.t., $95 \%$.

gave enone $\mathbf{1 2}$ in an acceptable yield. The diene $\mathbf{1 3}$ was readily prepared by usual procedure from $\mathbf{1 2}$.

Thus, the stage was set for the formation of the third 6membered ring. In refluxing toluene, the $[4+2]$ cycloaddition of dimethyl fumarate to the diene $\mathbf{1 3}$ took place selectively from the opposite side of OAr to afford the desired 14a as a major product together with a small amount of its epimer 14b (Scheme 4). The stereochemistry of each product was determined by NOE experiments. Reduction of 14a to a diol followed by treatment with TBAF afforded a thermodynamically most favorable trans-fused ketone. Protection of the diol moiety with TBS provided 15, which was converted into an enone 16. A stereoselective introduction of methyl on the C(3)-position to form a quaternary carbon was a next critical aspect of our synthetic study. While usual procedures for conjugate addition (e.g., $\mathrm{Me}_{2} \mathrm{CuLi}_{1}{ }^{18} \mathrm{MeMgBr}$-cat.Cu(I)-TMSCl ${ }^{19}$ ) did not work with the enone $\mathbf{1 6}$, a $\mathrm{Cu}(\mathrm{II})$-salicylidene-iminato complex 19 catalyzed reaction ${ }^{20}$ effected the addition to afford methylation product in good yield. However, no stereoselection was observed (Equation 1), and we had to modify the structure of the substrate appropriate for the $\pi$ facial selection.

After various examinations, we found that the cyclic silyl ether 17, easily available from $\mathbf{1 6}$ via a protective group manipulation, ${ }^{21}$ was the substrate of choice for the stereo-
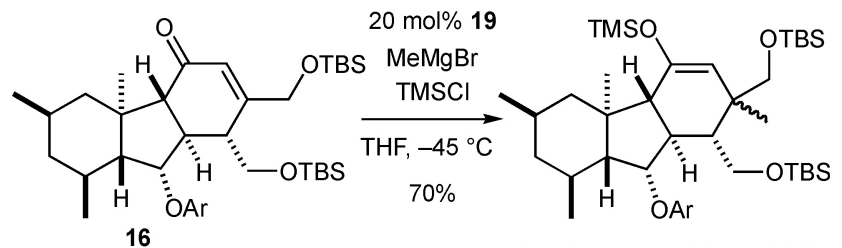

stereoisomeric mixtures (1:1)

Equation 1 
selective 1,4-addition. When $\mathbf{1 7}$ was subjected to the above conditions, the addition product $\mathbf{1 8}$ was obtained as a sole product (Scheme 4). The complete stereoselectivity observed in this conjugate addition could be explained by considering the structural feature of $\mathbf{1 7}$ shown in Figure 2.

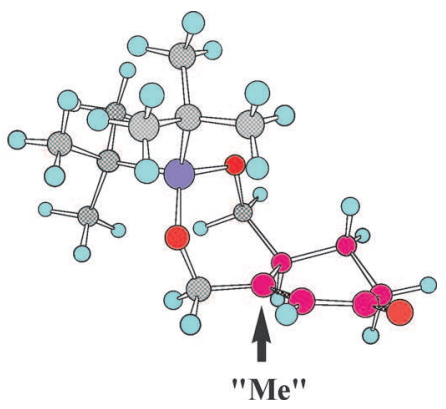

Figure 2 An optimized structure of the right half of $\mathbf{1 7}$.<smiles>C=C(OC(C)(C)C)C1=C[C@@H](O)C2C(C)CC(C)C[C@]12C(=O)OCCCC</smiles>

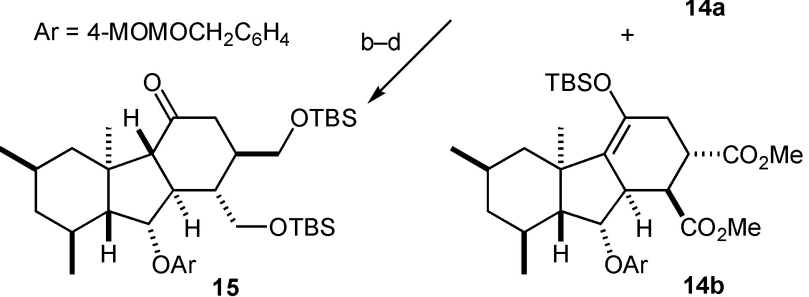

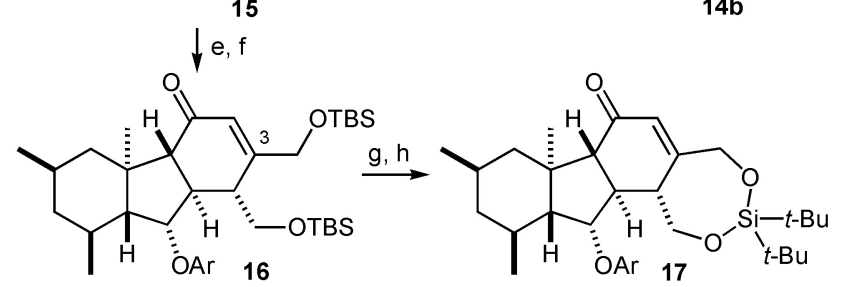<smiles></smiles><smiles>COC1=C[C@]2(C)CO[Si](C(C)(C)C)(C(C)(C)C)OC[C@H]2[C@@H]2[C@@H](O)C3C(C)CC(C)C[C@]3(C)[C@H]12</smiles>

18

Scheme 4 Reagents and conditions: a) dimethyl fumarate, toluene, reflux, $10 \mathrm{~h}, \mathbf{1 4 a} 83 \%$, 14b $17 \%$; b) $\mathrm{LiBH}_{4}$, THF-MeOH, $0{ }^{\circ} \mathrm{C}$ to r.t., $1 \mathrm{~d}, 91 \%$; c) TBAF, THF, $0{ }^{\circ} \mathrm{C}$ to r.t., $2 \mathrm{~h}$; d) TBSCl, imidazole, DMF, r.t., 1 h, $97 \%$ (2 steps); e) LDA, TMSCl, THF, $-78^{\circ} \mathrm{C}, 3 \mathrm{~h}$; f) $\left.\mathrm{Pd}(\mathrm{OAc})_{2}, \mathrm{MeCN}, 50{ }^{\circ} \mathrm{C}, 10 \mathrm{~h} ; \mathrm{g}\right) \mathrm{TBAF}, \mathrm{THF}, 0{ }^{\circ} \mathrm{C}$ to r.t., $2 \mathrm{~h}$; h) $(t$ $\mathrm{Bu})_{2} \mathrm{Si}(\mathrm{OTf})_{2}, 2,6$-lutidine, $\mathrm{CH}_{2} \mathrm{Cl}_{2},-78$ to $-45{ }^{\circ} \mathrm{C}, 4 \mathrm{~h}, 58 \%$ (based on 15); i) $\mathrm{MeMgBr}$, TMSCl, $10 \mathrm{~mol} \% \mathrm{19}$, THF, $-45^{\circ} \mathrm{C}, 44 \mathrm{~h}, 84 \%$ (single stereoisomer).

The trimethylsiloxy group in $\mathbf{1 8}$ was replaced with methyl group via three sequential steps, silyl-lithium exchange, ${ }^{22}$ triflation with Comins reagent, ${ }^{23} \mathrm{Pd}(0)-\mathrm{Me}_{2} \mathrm{Zn}$ reagents, ${ }^{24}$ affording 20 (Scheme 5). Compound 20 carries all required functionalities in the tricarbocyclic core of
GKK1032s with correct stereochemistry. Since $\mathbf{2 0}$ was isolated as a crystalline compound, the relative configuration was unambiguously determined by X-ray crystallographic analysis (Figure 3 ). ${ }^{25}$

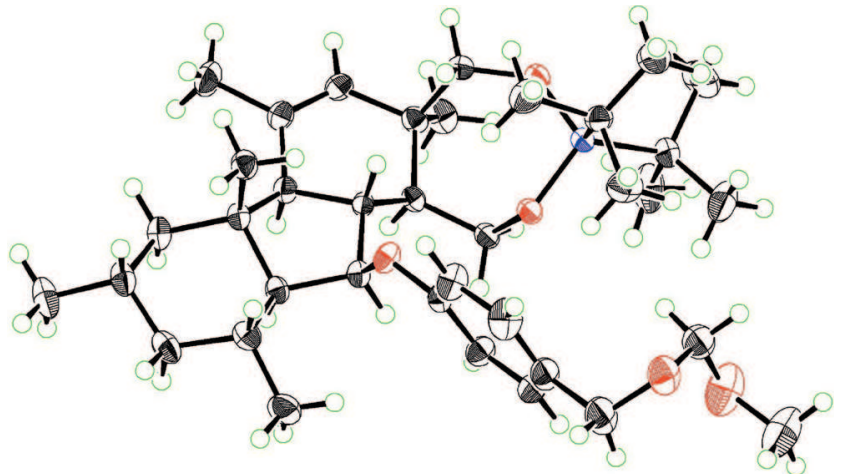

Figure 3 ORTEP drawing of $\mathbf{2 0 .}$

After deprotection of the silylene in $\mathbf{2 0}$ with TBAF, regioselective TBDPS ether formation was nicely carried out under low temperature conditions to give 21a in preference to $\mathbf{2 1 b}$. Oxidation of the remaining hydroxy group in 21a followed by Wittig reaction ${ }^{26}$ led to 22, which was converted into aldehyde $\mathbf{2 3}$ via usual protecting group manipulation. Thus, we established a highly stereoselective synthetic route from the known ketone $\mathbf{4}$ to the aldehyde 23, which could be a useful common intermediate in the total synthesis of GKK1032 family.<smiles>COC1=C[C@]2(C)CO[Si](C(C)(C)C)(C(C)(C)C)OC[C@H]2[C@H]2[C@H](O)C3(C)C(C)CC(C)C[C@]3(C)[C@H](O)C12C</smiles>

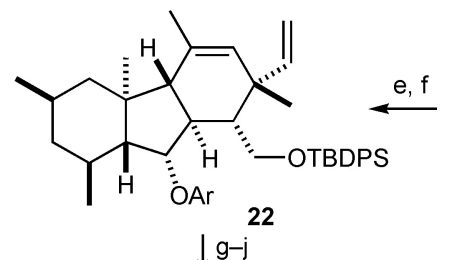

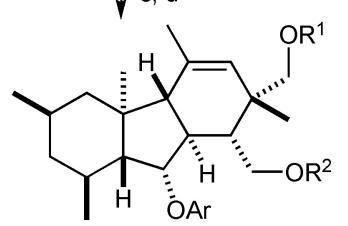

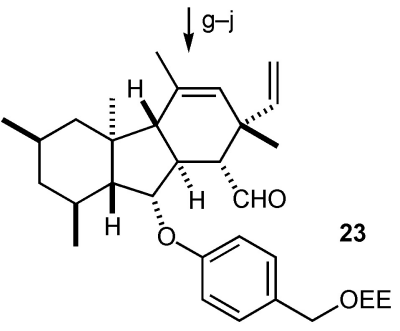
21a $R^{1}=H, R^{2}=$ TBDPS 21b $R^{1}=$ TBDPS, $R^{2}=H$<smiles>Nc1ccc(Cl)cn1</smiles>
24

Scheme 5 Reagents and conditions: a) $\mathrm{MeLi}$, THF, $-78{ }^{\circ} \mathrm{C}$ to r.t., 2 h, then $24,-78{ }^{\circ} \mathrm{C}, 16 \mathrm{~h}, 86 \%$; b) $\mathrm{Me}_{2} \mathrm{Zn}, \mathrm{Pd}\left(\mathrm{PPh}_{3}\right)_{4}$, THF, $0{ }^{\circ} \mathrm{C}$ to r.t., $28 \mathrm{~h}, 95 \%$; c) TBAF, THF, r.t., $20 \mathrm{~h}$; d) TBDPSCl, $\mathrm{Et}_{3} \mathrm{~N}, 10 \mathrm{~mol} \%$ DMAP, $\mathrm{CH}_{2} \mathrm{Cl}_{2},-78{ }^{\circ} \mathrm{C}$ to $-45{ }^{\circ} \mathrm{C}, 4 \mathrm{~h}, 21 \mathrm{a} 80 \%$, 21b $13 \%$; e) $(\mathrm{COCl})_{2}$, DMSO, $\mathrm{Et}_{3} \mathrm{~N},-78{ }^{\circ} \mathrm{C}$ to $0{ }^{\circ} \mathrm{C}, 1 \mathrm{~h}, 95 \%$; f) $\mathrm{MePh}_{3} \mathrm{PBr}, \mathrm{BuLi}$, THF, $0{ }^{\circ} \mathrm{C}, 2 \mathrm{~h}, 96 \%$; g) $2 \mathrm{M} \mathrm{HCl}$, aq THF, $35^{\circ} \mathrm{C}, 8 \mathrm{~h}, 95 \%$ (3 recycles); h) ethyl vinyl ether, $10 \mathrm{~mol} \%$ PPTS, $\mathrm{CH}_{2} \mathrm{Cl}_{2}$, r.t., $3 \mathrm{~h}$; i) TBAF, MS $4 \AA$, THF, $40^{\circ} \mathrm{C}, 17 \mathrm{~h}$, quant. (2 steps); j) $\mathrm{SO}_{3}$.pyridine, $\mathrm{Et}_{3} \mathrm{~N}$, DMSO, r.t., $1.5 \mathrm{~h}, 89 \%$. 
We are now investigating the total synthesis of GKK1032s, and will describe this in the near future.

\section{Acknowledgment}

The authors acknowledge Dr. M. Minoura in Department of Chemistry, Faculty of Science, Kitasato University, for X-ray crystallographic analysis of $\mathbf{2 0 .}$

\section{References}

(1) (a) Koizumi, F.; Hasegawa, A.; Ando, K.; Ogawa, T.; Hara, M. Jpn. Kokai Tokkyo Koho, JP 2001247574 A2 20010911, 2001; Chem. Abstr. 2001, 135, 209979. (b) Hasegawa, A.; Koizumi, F.; Takahashi, Y.; Ando, K.; Ogawa, T.; Hara, M.; Yoshida, M. 43rd Symposium on the Chemistry of Natural Products, Symposium Papers; Osaka: Japan, 2001, 467.

(2) Omura, S.; Komiyama, H.; Hayashi, M.; Masuma, R.; Fukaumi, A. Jpn. Kokai Tokkyo Koho, JP 2002255969 A2 20020911, 2002; Chem. Abstr. 2002, 137, 231476.

(3) He, H. Y.; Yang, H. Y.; Bigelis, R.; Solum, E. H.; Greenstein, M.; Carter, G. T. Tetrahedron Lett. 2002, 43, 1633.

(4) Oikawa, H. J. Org. Chem. 2003, 68, 3552.

(5) Hagiwara, H.; Sakai, H.; Uchiyama, T.; Ito, Y.; Morita, N.; Hoshi, T.; Suzuki, T.; Ando, M. J. Chem. Soc., Perkin Trans. $12002,583$.

(6) McKenzie, T. C. J. Org. Chem. 1974, 39, 629.

(7) Renoud-Grappin, M.; Vanucci, C.; Lhommet, G. J. Org. Chem. 1994, 59, 3902.

(8) Hajos, Z. G.; Parrish, D. R. J. Org. Chem. 1973, 38, 3239.

(9) (a) Provita, J.; Ocadlik, R.; Klinotova, E.; Klinot, J.; Vystrcil, A. Collect. Czech. Chem. Commun. 1987, 52, 501. (b) Kawabata, T.; Grieco, P. A.; Sham, H.-L.; Kim, H.; Jaw, J. Y.; Tu, S. J. Org. Chem. 1987, 52, 3346. (c) Mehta, G.; Murthy, A. N. J. Org. Chem. 1987, 52, 2875. (d) Ihara, M.; Tokunaga, Y.; Fukumoto, K. J. Org. Chem. 1990, 55, 4497.

(10) Mancuso, A. J.; Swern, D. Synthesis 1981, 165.
(11) (a) Minami, I.; Takahashi, K.; Shimizu, I.; Kimura, T.; Tsuji, J. Tetrahedron 1986, 42, 2971. (b) Ito, Y.; Hirao, T.; Saegusa, T. J. Org. Chem. 1978, 43, 1011.

(12) Krafft, M. E.; Dasse, O. A.; Fu, Z. J. Org. Chem. 1999, 64, 2475 .

(13) (a) Nicholls, B.; Whiting, M. C. J. Chem. Soc. 1959, 551. (b) Ghavshou, M.; Widdowson, D. A. J. Chem. Soc., Perkin Trans. 1 1983, 3065.

(14) Tanaka, T.; Mikamiyama, H.; Maeda, K.; Ishida, T.; In, Y.; Iwata, C. Chem. Commun. 1997, 2401.

(15) (a) Corey, E. J.; Erickson, B. W. J. Org. Chem. 1971, 36, 3553. (b) Ho, T.-L.; Wong, C. M. Can. J. Chem. 1972, 50, 3740. (c) Ho, T.-L.; Ho, C. H.; Wong, C. M. J. Chem. Soc., Chem. Commun. 1972, 791. (d) Fetizon, M.; Jurion, M. J. Chem. Soc., Chem. Commun. 1972, 382.

(16) Stork, G.; Zhao, K. Tetrahedron Lett. 1989, 30, 287.

(17) Langille, N. F.; Dakin, L. A.; Panek, J. S. Org. Lett. 2003, 5 , 575.

(18) Posner, G. H. Org. React. 1972, 19, 1.

(19) Horiguchi, Y.; Nakamura, E.; Kuwajima, I. Org. Synth., Coll. Vol. IX; Wiley and Sons: New York, 1998, 564.

(20) Sakata, H.; Aoki, Y.; Kuwajima, I. Tetrahedron Lett. 1990, 31,1161

(21) Corey, E. J.; Hopkins, P. B. Tetrahedron Lett. 1982, 23, 4871.

(22) (a) Torneiro, M.; Fall, Y.; Castedo, L.; Mourino, A. Tetrahedron Lett. 1992, 33, 105. (b) Denmark, S. E.; Fujimori, S. Org. Lett. 2002, 4, 3473.

(23) Comins, D. L.; Dehghani, A. Tetrahedron Lett. 1992, 33, 6299.

(24) Marshall, J. A.; Van Devender, E. A. J. Org. Chem. 2001, 66, 8037.

(25) Crystallographic data for 22: formula, $\mathrm{C}_{37} \mathrm{H}_{60} \mathrm{O}_{2} \mathrm{Si}$; FW, 612.94; crystal system, orthorhombic; space group, $P 2_{1} 2_{1} 2_{1}$; $a=11.7726$ (4) $\AA, b=12.9543$ (4) $\AA, c=23.5023$ (8) $\AA$; $V=3584.2(2) \AA^{3} ; Z=4 ; T=170 \mathrm{~K} ; D_{\text {calcd }}=1.136 \mathrm{~g} \mathrm{~cm}^{-1}$; $\lambda\left(\mathrm{MoK}_{a}\right)=0.71070 \AA$ 品 $R 1=0.0418[\mathrm{I}>2 \sigma(I)] ; w R 2=$ $0.1082 ; \operatorname{GOF}\left(F^{2}\right)=1.064$.

(26) (a) Danishefsky, S.; Schuda, P. F.; Kitahara, T.; Etheredge, S. J. J. Am. Chem. Soc. 1977, 99, 6066. (b) Stevens, R. V.; Albizati, K. F. J. Org. Chem. 1985, 50, 632. 